\title{
Vitamin D Deficiency and Its Health Consequences in Africa
}

\author{
Ann Prentice - Inez Schoenmakers • \\ Kerry S. Jones $\cdot$ Landing M. A. Jarjou • \\ Gail R. Goldberg
}

Published online: 28 April 2009

(C) Humana Press Inc. 2009

\begin{abstract}
Africa is heterogeneous in latitude, geography, climate, food availability, religious and cultural practices, and skin pigmentation. It is expected, therefore, that prevalence of vitamin D deficiency varies widely, in line with influences on skin exposure to UVB sunshine. Furthermore, low calcium intakes and heavy burden of infectious disease common in many countries may increase vitamin D utilization and turnover. Studies of plasma 25OHD concentration indicate a spectrum from clinical deficiency to values at the high end of the physiological range; however, data are limited. Representative studies of status in different countries, using comparable analytical techniques, and of relationships between vitamin D status and risk of infectious and chronic diseases relevant to the African context are needed. Public health measures to secure vitamin D adequacy cannot encompass the whole continent and need to be developed locally.
\end{abstract}

Keywords Rickets - Osteomalacia - Vitamin D status . 25-hydroxyvitamin D · Vitamin D turnover .

Calcium intake $\cdot$ Sunlight $\cdot$ Children

\section{Introduction}

This article addresses the prevalence of vitamin D deficiency and issues that need to be considered when considering vitamin D status (supply, sufficiency, utilisation)

A. Prentice $(\bowtie)$ - I. Schoenmakers · G. R. Goldberg

Human Nutrition Research, MRC, Cambridge, UK

e-mail: ann.prentice@mrc-hnr.cam.ac.uk

A. Prentice - K. S. Jones - L. M. A. Jarjou - G. R. Goldberg MRC Keneba, MRC, Keneba, The Gambia and potential health consequences in Africa. The reader is referred to other articles that discuss in detail some of the general background to vitamin $\mathrm{D}$, including evolution, biologic functions and dietary requirements; photobiology; assays; pregnancy and lactation; calcium and vitamin D deficient rickets and children's bone health; dietary sources; sun deprivation and health consequences. Where appropriate these are also considered here because they are particularly relevant to, or may be different in, an African context.

Vitamin D status and supply is influenced by sunshine exposure, diet and underlying health conditions. People acquire vitamin $\mathrm{D}$ by cutaneous synthesis following exposure to sunlight, and from the diet. It is not possible to generalize about the proportions contributed by different sources because this varies considerably around the world, across population groups, and between individuals, mainly because of wide differences in skin exposure to ultraviolet B (UVB) radiation, the efficiency of cutaneous synthesis, dietary supplementation and food fortification practices [1]. Reliance on dietary sources of vitamin $\mathrm{D}$ is greatest during the winter at latitudes outside the tropics $\left(>30^{\circ} \mathrm{N}\right.$ and $>30^{\circ} \mathrm{S}$ ) and among people with restricted skin sunshine exposure $[1,2]$. The endogenous supply of vitamin D3 (cholecalciferol) depends on the skin's exposure to UVB radiation at wavelengths of $290-315 \mathrm{~nm}$, the efficiency of cutaneous vitamin D synthesis, and the extent to which vitamin $\mathrm{D}$ is degraded within the skin [3-5]. The quantity of UVB radiation of the relevant wavelengths that reaches the skin depends on many factors (see section "Ultraviolet radiation and skin pigmentation") including time of day, and, at latitudes north and south from approximately $30^{\circ} \mathrm{N}$ and $30^{\circ} \mathrm{S}$, on month of the year. In the summer months, however, the amount of UVB containing wavelengths that can generate vitamin D synthesis is the same at all latitudes 
[6]. In addition, even when there is abundant sunshine, the extent of UVB skin exposure depends on clothing, living and working environments and sunscreen use [7].

The status marker for vitamin $\mathrm{D}$, plasma 25 hydroxy vitamin D (25OHD) concentration, depends on factors that determine the balance between supply and turnover [8]. Supply depends on factors including host, dietary and environmental factors. Turnover of $25 \mathrm{OHD}$ and 1,25 dihydroxy vitamin $\mathrm{D}\left(1,25(\mathrm{OH})_{2} \mathrm{D}\right)$ in renal and extra-renal tissues depends on many factors, including nutrient intake (of which calcium is the most important), protein-energy malnutrition, body composition, high disease burden and innate characteristics such as polymorphisms in the VDR and DBP genes [8-12].

\section{The Continent of Africa}

\section{Geography, Topography, and Climate}

Africa is the world's second largest continent after Asia, occupying an area of about 30 million $\mathrm{km}^{2}$ including adjacent islands. Thus, Africa represents about $20 \%$ of the earth's total land area. It is the only continent that straddles the equator and has both northern and southern temperate zones. The distance between the most northerly $\left(\sim 37^{\circ} \mathrm{N}\right.$ in Tunisia) and most southerly $\left(\sim 34^{\circ} \mathrm{S}\right.$ in South Africa) points is $\sim 8000 \mathrm{~km}$. From the westernmost $\left(\sim 17^{\circ} \mathrm{W}\right.$, Cape Verde) to the easternmost $\left(\sim 51^{\circ} \mathrm{E}\right.$ in Somalia) points is $\sim 7400 \mathrm{~km}$. Some of the larger African countries are distributed across more than one latitude band. The climate ranges from tropical to subarctic and the topography includes deserts, mountains, grassland plateaus, lakes and rivers. Much of northern Africa is predominantly desert or arid land, and central and southern areas contain deserts, savannah plains and dense rainforest. All these features affect the available water supply, food sources, population distribution and the sorts of clothing worn (e.g. for warmth, protection against the sun, wind, rain and sand). The weather in Africa is also very variable, and temperatures vary greatly throughout the continent. Many countries have wet and dry seasons which in turn affect food availability, farming activities and therefore levels of physical activity and weight, and body composition changes, morbidity and mortality, including incidence of low birthweight infants, and the prevalence and incidence of malaria. About $74 \%$ of people in Africa live in areas that are highly endemic for malaria, $19 \%$ in epidemic-prone areas and only $7 \%$ in low-risk or malaria-free areas [13].

\section{Demography}

Africa is the second most populated continent after Asia with more than 900 million people who account for $\sim 14 \%$ of the world's population. Africa comprises more than 50 countries ranging in landmass from 2.4 million $\mathrm{km}^{2}$ (Sudan) to $455 \mathrm{~km}^{2}$ (The Seychelles) (www.fao.org). Individual counties are not only very diverse with respect to size but also population ranging from 145,000,000 (Nigeria) to 86,000 (The Seychelles) and the proportion of the population that live in urban areas (10\% Burundi; $84 \%$ Gabon; average $38 \%$ in WHO Africa Region) [14]. Across the continent as a whole $\sim 40 \%$ of Africans are Christian, $\sim 40 \%$ are Muslim and $\sim 20 \%$ follow other religions (including indigenous African religions, Hinduism and Judaism). There is a great deal of variation within and between countries and population groups. Some religious beliefs and traditional practices can impact on customary dress and dietary habits.

\section{Ultraviolet Radiation and Skin Pigmentation}

The factors that affect the amount of ambient UVB radiation include stratospheric ozone levels, cloud cover, latitude, season, and lower atmospheric pollution. The factors that affect an individual's UVB exposure and biological effects of UVB include sun-seeking and sun protective behaviours, skin pigmentation, and cultural dress and behaviour [15]. The concentration of atmospheric ozone that is able to absorb UVB, and the amount and spectral structure of radiation reaching the body is dependent on the angle at which the sun's rays pass through the atmosphere; at lower latitudes, closer to the equator there is more intense radiation. At higher altitudes, UVB radiation is increased because there is less mass of air for solar radiation to pass through. Time of day, season and presence of clouds, dust, haze and various organic compounds can alter the intensity of incident solar radiation. The UV Index, the maximum UV level on a given day during the 4-h period around solar noon, varies according to time and place, and with season and latitude. Levels of total annual UV radiation (UVR) vary approximately fourfold globally, but within any area there can be a tenfold difference in personal exposure related to behavioural and cultural factors. Individual exposure within population groups may vary from one tenth to ten times the mean exposure in a particular location.

Different skin pigmentations are thought to have developed to protect against high ambient UVR whereby those inhabiting low latitudes with high UVR have darker pigmentation to protect against deleterious effects, whilst those inhabiting higher latitudes developed fair skin to maximize vitamin D production from much lower ambient UVR. However, in recent history, migration of people of different skin types means that skin pigmentation is not necessarily so suited to the environment. For the purposes of assessing the effects of UVR on different skin 
pigmentations, a scale classifying skin types for UVR sensitivity is used which comprises six skin types [16, 17]. This is often broken down into three broader skin pigmentation groups [15]: lightly pigmented (Caucasian fair, medium and darker skin, skin types I-IV), intermediate pigmentation (Asian or Indian skin, skin type V), and deeply pigmented (Afro-Caribbean or black skin, skin type VI). Latitude provides a rough approximation to global variation in UVR, so in epidemiological studies of UVR, groups of different races/ethnicities can be categorized under these broad headings, but with recognition that there is great individual variation within racial and ethnic groups [15]. An illustration of the distribution of skin types at different latitudes in Africa is shown in Table 1.

The efficiency of vitamin D cutaneous synthesis depends on skin pigmentation and age [18, 19]. Very little data from controlled interventional research are available on the differences in efficiency in vitamin D synthesis between different skin types, but a fourfold difference has been reported between types II and V [20]. However, evidence from studies in African-American Blacks and Indians suggest that there is no difference in the total capacity of cutaneous vitamin D synthesis between individuals with different skin types [21, 22]. There are no studies in the literature investigating cutaneous synthesis in indigenous African people.

On the African continent, seasonality in cutaneous vitamin D synthesis would be expected in countries such as Morocco, Tunisia, Algeria, Libya, Egypt, and South Africa which lie at latitudes $>30^{\circ} \mathrm{N}$ and $>30^{\circ} \mathrm{S}$ [23]. This is supported by studies in hip fracture patients in South Africa [24] and in pregnant women and their newborns in Algeria [25]. In countries close to the equator, seasonality in cutaneous vitamin D synthesis might be expected due to differences in cloud cover (http://nadir.nilu.no/,olaeng/ fastrt/VitaminD.html). In two studies, in The Gambia $\left(14^{\circ} \mathrm{N}\right)$ and Guinea Bissau $\left(12^{\circ} \mathrm{N}\right)$, no significant effect of season on plasma $25 \mathrm{OHD}$ concentrations was found [26, 27]. However, seasonal variations in plasma $25 \mathrm{OHD}$ concentration have been reported in older people in The Gambia where lower concentrations were observed in December-February [1].

\section{Diet and Foodstuffs}

The African diet is very heterogeneous and varies from region to region. Historically, the climate, geography and history largely dictated where populations became

Table 1 WHO sub-regions ${ }^{a}$ comprising African countries, by latitude, and \% distribution of population within a region in that latitude with different skin pigmentation (compiled from information in Ref. [15])

\begin{tabular}{|c|c|c|c|c|}
\hline Latitude & WHO sub-region, country ( $\%$ of country in latitude band, if not $100 \%$ ) & $\begin{array}{l}\text { Lightly } \\
\text { pigmented }\end{array}$ & $\begin{array}{l}\text { Intermediate } \\
\text { pigmentation }\end{array}$ & $\begin{array}{l}\text { Deeply } \\
\text { pigmented }\end{array}$ \\
\hline \multirow[t]{3}{*}{$0-10$} & $\begin{array}{l}\text { Africa D: Cameroon, Equatorial Guinea, Gabon, Ghana, Liberia, Sao Tome } \\
\text { and Principe, Seychelles, Sierra Leone, Angola (50\%), Benin }(90 \%), \\
\text { Nigeria (50\%), Guinea (50\%), Togo }\end{array}$ & $<1$ & $<1$ & 41 \\
\hline & $\begin{array}{l}\text { Africa E: Burundi, Central African Republic, Congo, Cote D'Ivoire, Kenya, } \\
\text { Rwanda, Democratic Republic of Congo ( } 95 \%) \text {, Ethiopia (50\%), Tanzania }\end{array}$ & $\ll 1$ & $<1$ & 59 \\
\hline & East Mediterranean D: Somalia, Sudan (20\%) & $<1$ & $<1$ & 3 \\
\hline \multirow[t]{3}{*}{$10-20$} & $\begin{array}{l}\text { Africa D: Cap Verde, Chad, Comoros, Gambia, Guinea-Bissau, Mauritius, } \\
\text { Niger, Senegal, Angola (50\%), Benin (10\%), Burkina Faso, Guinea (50\%), } \\
\text { Madagascar (50\%), Mauritania (50\%), Nigeria (50\%), Mali }\end{array}$ & $<1$ & 2.5 & 42 \\
\hline & $\begin{array}{l}\text { Africa E: Eritrea, Malawi, Zimbabwe, Botswana (10\%), Democratic } \\
\text { Republic of Congo (5\%), Mozambique (70\%), Namibia (20\%), Ethiopia } \\
(50 \%)\end{array}$ & $<1$ & $<1$ & 22 \\
\hline & East Mediterranean D: Sudan (79\%) & 8 & 1 & 4 \\
\hline \multirow[t]{4}{*}{$20-30$} & Africa D: Algeria (10\%), Madagascar (50\%), Mauritania (50\%) & $<1$ & 2 & 2 \\
\hline & $\begin{array}{l}\text { Africa E: Lesotho, Swaziland, Zambia, Botswana (90\%), Mozambique } \\
\quad(30 \%) \text {, Namibia }(80 \%) \text {, South Africa }(80 \%)\end{array}$ & 1 & 1 & 13 \\
\hline & East Mediterranean B: Libya (50\%), Morocco (10\%) & 22 & 2 & $<1$ \\
\hline & East Mediterranean D: Sudan (1\%), Egypt (50\%) & $<1$ & 34 & $<1$ \\
\hline \multirow[t]{4}{*}{$30-40$} & Africa D: Algeria (90\%) & $<1$ & 10 & $<1$ \\
\hline & Africa E: South Africa (20\%) & $<1$ & $<1$ & 2 \\
\hline & East Mediterranean B: Libya (50\%), Morocco (90\%), Tunisia & 70 & 2 & $<1$ \\
\hline & East Mediterranean D: Egypt (50\%) & 14 & 34 & $<1$ \\
\hline
\end{tabular}

${ }^{a}$ Countries are listed according to both WHO Africa regions (D and E) and other countries on the African continents which come under WHO East Mediterranean regions B and D. All these WHO regions encompass the countries mentioned in this article 
pastoralists, agriculturalists and hunter-gatherers, and therefore local availability and ability to store fresh and salt-water fish, meat, poultry, and milk; and the kinds of crops that could be grown and thus traditionally consumed. Over the centuries there have been many secular changes in diet and food composition. There are now also 'westernised' populations in most African countries; the proportions differ between and within countries and are changing as countries transit from less to more developed, and depending on natural and manmade environment. This transition affects dietary patterns, the sorts of foods consumed, nutrient intakes and sources of nutrients.

\section{Indicators of Health and Burden of Disease in Africa Which May Affect, or be Affected by Vitamin D Status}

Africa is associated with a high prevalence of economic disadvantage and high burden of disease. This is still mostly infectious disease but increasingly also non-communicable disease. The various factors that may be especially important to consider in the context of Africa and that may affect the interpretation of vitamin D status and deficiency are outlined later.

In addition, vitamin $\mathrm{D}$ status has been implicated in the progression of disease, and this can add another layer of complexity in interpreting vitamin D status measurements. The emerging work on the possible relationship between vitamin D status and disease risk reduction (TB and HIV/ AIDS) is discussed in section "Health consequences of poor vitamin D status In Africa”.

\section{Malnutrition}

The percentage of infants born with low birthweight is $\sim 14 \%$ in the WHO African region and in some African countries is $>20 \%$. There are many reasons for low birthweight but a major contributory factor in Africa is low maternal weight gain due to general shortage of foods or energy or specific nutrients. Low birthweight is the major risk factor for infant mortality and morbidity. The most recent estimate of infant mortality rate in the WHO Africa region is 94 per 1000 live births. In some African countries the rate is $>100$. These figures are in the context of a global rate of 49. The under 5 mortality rate in Africa is 157 per 1000 live births and in some African countries is $>200$ per 1000 live births (global rate $=71$ ). Recent estimates suggest that $43 \%$ of children in Africa are stunted and $23 \%$ are underweight for their age. In some African countries, the prevalence is $>50 \%$ and $>30 \%$, respectively [14]. Vitamin $\mathrm{D}$ or calcium deficiency rickets are often found where more general malnutrition is prevalent.
Vitamin D Intake

There are very little data from Africa on dietary vitamin D intakes, although sources of other nutrients and food patterns indicate that, as observed elsewhere, food intake is unlikely to make a substantial contribution because there are few naturally occurring food sources that are rich in vitamin D (meat, offal, egg yolk, oily fish), and these are not eaten at all or only rarely [28-30]. It is impossible to quantify or generalise about the possible contribution of vitamin $\mathrm{D}$ in foods supplied as food aid (some of which may be fortified) or in the form of multiple micronutrient supplements.

\section{Low Calcium Intake}

Where dietary calcium intakes have been assessed in African countries, the values from infants, children and adults are considerably below recommendations, and close to biological requirements. Calcium intakes of 200$300 \mathrm{mg} /$ day have been reported from Egypt, Kenya, Nigeria, The Gambia and South Africa [31]. Dairy product intake is minimal in many African counties and typical diets also contain high amounts of phytates, oxalates and tannins that are likely to reduce the absorption of calcium. Children with bone deformities consistent with rickets but without overt vitamin D deficiency have been reported from Nigeria, The Gambia and South Africa. Dietary calcium deficiency has been identified as a possible contributing factor due to its effects on the metabolism of vitamin D [32].

\section{Fluorosis}

Fluoride is present in all natural waters, but higher concentrations are found in groundwater from calcium-poor aquifers and in areas where fluoride-bearing minerals are common. In Africa the latter applies particularly to areas in the East African rift system and many lakes in the Rift Valley (Sudan, Ethiopia, Uganda, Kenya and Tanzania) have very high levels of fluoride. High groundwater fluoride concentrations are associated with igneous and metamorphic rocks including those in western Africa (e.g. Nigeria, Senegal) and South Africa [33]. Endemic skeletal fluorosis has been associated with hypocalcaemia, phosphaturia and raised concentration of $1,25(\mathrm{OH})_{2} \mathrm{D}$ [34]; all indices that are associated with various forms of rickets.

\section{Tropical Enteropathy}

Tropical enteropathy (tropical sprue) is common in many parts of Africa. It is characterised by intestinal permeability and poor absorption, abnormal villus structure and function 
in adults and children and thought to be caused by many factors including repeated episodes of infection and diarrhea [35-39]. Poor nutrient absorption of calcium and other factors that may affect vitamin D metabolism may impact on vitamin D status, which in turn may affect gastrointestinal health. Thus tropical enteropathy may be a contributing factor in vitamin D deficiency and conversely may be exacerbated by poor vitamin D status. However, although these links are plausible, they have not yet been explored.

\section{Malaria}

Of the 350-500 million estimated cases of clinical malaria each year, nearly $60 \%$ of cases and $90 \%$ of deaths occur in Africa south of the Sahara with $75 \%$ of these in children under 5 [13]. Malaria affects everyone, but children under 5 years of age and pregnant women are the most vulnerable groups because of lower immunity. Malaria contributes to health problems and deaths in many ways, especially in younger children. These include frequent acute infections; anaemia as a result of repeated or chronic malaria infection; malaria in pregnancy resulting in low birth weight in infants; increased susceptibility to other diseases such as respiratory infections and diarrhea [40]. The immunomodulatory properties of vitamin D discussed in section "Health consequences of poor vitamin D status In Africa" may also play a role in the progression of malaria and its co-morbidities.

\section{HIV/AIDS}

Sub-Saharan Africa is the region most affected by HIV/ AIDS. In 2007 one in three people in the world with HIV lived in sub-Saharan Africa; a total of 22.5 million people. Cause-specific mortality rates per 100,000 population in 2006 were 203 for HIV/AIDS (compared with a global rate of 34); 56 for TB among HIV-negative people (global rate 22); 26 for TB among HIV-positive people (global rate 4). The mean prevalence in Africa (estimated in 2005) of HIV among people over 15 years of age is 4459 per 100,000 population (global figure is 662) and in some African countries the figures are $>20,000$ [14].

\section{Tuberculosis}

Globally tuberculosis (TB) is the second highest cause of death from infectious disease and is responsible for more deaths in those individuals infected with HIV than any other infectious disease [41]. Almost 30\% of TB cases and $34 \%$ of TB-related deaths occur in Africa, and it is estimated that between 1990 and 2005 the incidence of TB more than doubled in many African countries [42]. The prevalence of TB in Africa (estimated in 2006) is 547 per 100,000 population, and is $>900$ in some African countries (global prevalence is 219) [14]. Although HIV infection is a major cause, poverty, inadequate healthcare (in terms of diagnosis and treatment) and drug resistance have all contributed [42].

\section{Non-Communicable Disease}

In addition to a high burden of infectious disease in Africa, secular changes in diet and lifestyle, particularly in North Africa and urban centres in sub-Saharan Africa, are leading to increases in cardiovascular disease, cancer, and obesity and its co-morbidities including hypertension and type 2 diabetes [43-47]. Low vitamin D status has been implicated in diabetes and cancer. Serum 25OHD has been found to be low in obese adults and may be due to sequestration of vitamin $\mathrm{D}$ in subcutaneous fat and its consequent reduced bioavailability [48]. Currently, cancer is estimated to cause only $4 \%$ of deaths in Africa, but because of large populations this equates to a large number of people, and furthermore, many cases are undiagnosed. The major cancers in African men are Kaposi's sarcoma (associated with HIV), liver, prostate, bladder, and oesophageal cancer, and non-Hodgkins lymphoma. In African women the major cancers are Kaposi's sarcoma, cervical, breast, liver, and ovarian cancer, and non-Hodgkins lymphoma [49].

\section{Health Consequences of Poor Vitamin D Status in Africa}

The classical effects of poor vitamin D status are rickets and osteomalacia, but there is also emerging evidence for a role of vitamin $\mathrm{D}$ in reduction in the progression or severity of TB and HIV/AIDS. The immunomodulatory effects of vitamin D means there are many potential health consequences of vitamin D deficiency in Africa where the infectious disease burden is high. Vitamin D deficiency may impact on the immune system by decreasing innate immunity and immune surveillance; decreasing $\mathrm{T}$ lymphocyte number and function; and disrupting the Th1/Th2 balance (vitamin D normally inhibits Th1 profile). Vitamin $\mathrm{D}$ deficiency in an African setting may impact on the progression of infectious diseases such as TB (see below), HIV (see below) and schistosomiasis [50].

Rickets and Osteomalacia

Well-established health consequences of vitamin D deficiency are rickets and osteomalacia. However, although vitamin D deficiency rickets is reported in Africa, there are 
very little data on the burden of disease this imposes, and on associations with malnutrition, poverty and other factors. It is therefore difficult to judge the extent to which primary vitamin D deficiency is a cause.

\section{Tuberculosis}

In Europe, as early as 1849 , cod liver oil was recognised as beneficial in the treatment of TB and led in the early 1900s to the widespread use of vitamin D as a therapeutic treatment for both cutaneous and pulmonary TB [51]. The use of sanatoria was based on the belief that fresh air and sun exposure led to a positive outcome in the treatment of TB. Recently, a potential mechanism has been elucidated. In an in vitro study using serum from African-Americans and Caucasians, it was demonstrated that recognition of mycobacterium tuberculosis particles by toll-like receptors on the surface of macrophages triggers the upregulation of VDR and CYP27B1 (1 alpha hydroyxlase) expression. Intracellular $1,25(\mathrm{OH})_{2} \mathrm{D}$ production and signalling upregulated production of the antimicrobial peptide, cathelicidin, that is able to destroy the intracellular mycobacterium. Importantly, the serum from African-Americans ( $\sim 20 \mathrm{nmol} / 125 \mathrm{OHD}$ vs. $\sim 80 \mathrm{nmol} / \mathrm{l}$ in Caucasians) was less efficient in upregulating cathelicidin [52].

Observational studies have demonstrated a link between low serum 25OHD concentration and susceptibility to TB [53-58], and patients with active TB have lower serum 25OHD concentration than contacts (tuberculin skin-test positive) from similar ethnic and social backgrounds [59]. Despite the high incidence of TB in Africa, only one study, from Guinea-Bissau (latitude $12^{\circ} \mathrm{N}$ ), has been published that compares patients with active TB and a control group. The latter consisted of both tuberculin skin test positive and negative subjects [27]. There was a high prevalence of plasma $25 \mathrm{OHD}<75 \mathrm{nmol} / \mathrm{l}$ in both groups but this was more common in patients than controls, although not after correction for socio-economic and demographic factors. However, mean serum 25OHD concentration remained lower in the TB group. A systematic review of studies conducted around the world, including in Kenyans, has recently concluded that low serum 25OHD is associated with greater risk of active TB [60]. However, although evidence suggests that lower vitamin D status is associated with increased risk of TB, none of the studies could disentangle cause and effect because of relatively small sample size.

Studies have investigated polymorphisms in the vitamin $\mathrm{D}$ receptor (VDR) gene in relation to $\mathrm{TB}$ and other diseases in Africa and elsewhere. The polymorphisms Taql and Fokl affect transcription and expression of the VDR protein and may result in functional effects, including susceptibility to $\mathrm{TB}$, response to anti-TB treatment, and potentially vitamin D metabolism. Furthermore, because the VDR interacts with vitamin D metabolism, the effect of polymorphisms may depend on vitamin D status. Studies in West Africa [61-63], South Africa [64, 65] and East Africa $[66,67]$ have investigated VDR polymorphisms and TB. However, results were inconsistent, and a systematic review and meta-analysis of VDR polymorphisms and TB concluded that results were inconclusive, studies included heterogeneous populations and were underpowered [68].

A further area of potential study is the use of vitamin D as an adjuvant to TB drug treatment [69]. A study in Egypt [70] in which vitamin D was administered to children with TB concluded that clinical outcome in patients that received vitamin $\mathrm{D}$ plus drug treatment was better than those who received treatment alone, although differences were not significant. A double-blind, placebo-controlled vitamin D supplementation trial was performed in Indonesia in patients with moderately advanced pulmonary TB. Those receiving vitamin D had a significantly higher rate of sputum conversion and increased radiological improvement compared with the placebo group [71]. In vitro work has shown a positive effect of vitamin D; a single dose of $2.5 \mathrm{mg}$ vitamin $\mathrm{D}$ was found to protect against reactivation of latent TB infection in whole blood from TB contacts [72]. A recent review [51] identified 14 reports of vitamin D administration to patients with pulmonary TB and concluded that major shortcomings in the studies prevented any clear conclusion from being drawn. Despite the strong mechanistic evidence for a possible beneficial role of vitamin $\mathrm{D}$ in the prevention and cure of $\mathrm{TB}$, appropriately powered, randomised controlled trials are needed, especially in Africa where the disease burden is high. In the next few years there should be more definitive evidence because a number of registered clinical trials (http://www. controlled-trials.com) are investigating the effects of adjuvant vitamin $\mathrm{D}$ therapy on recovery from $\mathrm{TB}$. One of these is a randomised, placebo-controlled double-blind trial [ISRCTN352121232] to investigate the therapeutic effects of oral vitamin $\mathrm{D}_{3}$ in 500 TB patients in Guinea-Bissau.

\section{HIV/AIDS}

The role of vitamin D in the progression of HIV infection is largely unknown and studies have mostly been performed in Western settings. A recent review considers in detail the evidence for a role of vitamin D in HIV infection [73]. Lower concentrations of $25(\mathrm{OH}) \mathrm{D}$ and $1,25(\mathrm{OH})_{2} \mathrm{D}$ among HIV-infected people have been attributed to defects in renal hydroxylation and increased utilization. An inverse association between $1,25(\mathrm{OH})_{2} \mathrm{D}$ concentrations and mortality has been reported from a small cohort of HIVinfected adults, and some cross-sectional studies have 
indicated positive correlations between $1,25(\mathrm{OH})_{2} \mathrm{D}$ and CD4+ cell counts.

Poor vitamin D status may compound the negative effects of HIV infection and HIV anti-retrovirals on the skeleton (as evidenced by high incidence of osteoporosis and osteopenia in infected individuals). Drugs used in HIV treatment may inhibit or stimulate cytochrome $\mathrm{P} 450$ enzymes. Vitamin D and its metabolites are catabolised by P450 enzymes and so stimulation may lead to vitamin D deficiency [62]. More studies are needed to confirm the associations between vitamin D status and HIV disease progression.

\section{Studies of Vitamin D Status in Africa}

Plasma 25OHD concentrations measured in studies conducted in Africa are summarised in Table 2. The data are from studies in healthy men and women, elderly people, pregnant and lactating women, healthy children and those with rickets, and clinical studies of TB and pneumonia. The subjects encompass people of different religions and in different settings. Full details of the studies can be found in the original references.

Table 2 highlights a number of important points. It demonstrates that there are very few nationally representative data; the studies are concentrated in The Gambia, Nigeria and South Africa and many studies compare control and 'unhealthy' groups. Table 2 also demonstrates that the 25OHD concentrations in the studies summarized should be compared and considered with caution; values were derived using 15 different methods. This leads to considerable variation in measured values for the same sample $[74,75]$ and the variation may even be larger when comparing older assays with modern methods. Only three papers reported the use of Quality Assurance materials and/ or participation in a quality assurance scheme (e.g. the Vitamin D External Quality Assessment Scheme, www.deqas.org).

With these caveats, generally when compared to national data in the UK and US [1], Table 2 suggests that values in African countries are higher. Mean values range from 7 to $150 \mathrm{nmol} / \mathrm{l}$ and the vast majority are above $25 \mathrm{nmol} / \mathrm{l}$. Collectively the prevalence of 25OHD $<25 \mathrm{nmol} / \mathrm{l}$ averages between $5-20 \%$ and $1-5 \%$ in most age groups in the UK and US. In North African countries there is a high prevalence of low vitamin D status, 25OHD is in the rachitic range. In tropical African countries the mean 25OHD values are high, but those with rickets have lower values than their peers in the same study, even though values are generally higher than $25 \mathrm{nmol} / \mathrm{l}$. Similarly, individuals with TB or pneumonia have lower values than control groups within the same study. Veiled women or women in purdah have a lower vitamin D status than their peers within the same country. Finally, a geographical gradient is apparent across the African continent; 25OHD is lower in North African countries and in South Africa compared with tropical African countries (i.e. higher in the latter), and within a country (different regions of South Africa).

\section{Conclusions}

Studies in Africa that have assessed 25OHD suggest a range of status from deficiency (in the rachitic range) to relatively high values. Well-established health consequences of vitamin D deficiency in Africa include rickets and osteomalacia. Emerging evidence also suggests that consequences also include increased susceptibility to infectious disease. In some African countries, risk factors for vitamin D deficiency may also include very low calcium intake, and the burden of infectious disease whereby utilisation and turnover of vitamin D is increased. Thus, a plasma 25OHD concentration considered to be sufficient in healthy people may not apply to those, for example, on very low calcium intakes, or who have tropical enteropathies, HIV or TB.

Underlying calcium nutrition must be considered when interpreting vitamin D status and considering the causes and health consequences of vitamin D deficiency in Africa. Vitamin D or calcium-deficiency rickets rather than being routinely screened for often presents as co-morbidities with infectious disease, for example pneumonia [76] and more work may give insights into the aetiology of various conditions where poor vitamin $\mathrm{D}$ status and/or low calcium intakes may be predisposing factors.

Studies are needed to confirm if emerging relationships between vitamin D status and health outcomes such as diabetes and cancer identified in Western countries can be replicated in African countries.

There is a need for the collection of nationally representative data of vitamin D status across Africa, with samples analysed using comparable techniques by accredited laboratories.

In summary, 'Africa' is not a homogenous entity with respect to geography, climate, water sources, food production and availability, or the religious and cultural practices, skin pigmentation, and burden of infectious and chronic disease of its people. All these factors are likely to affect and/or be affected by vitamin D status, and therefore how vitamin D deficiency is defined and its health consequences determined. It is therefore important to recognise that policy aspects of vitamin D cannot therefore encompass the whole continent of Africa, but need to be considered in a more local context. 
Table 2 Studies that include assessment of vitamin D status conducted in Africa

\begin{tabular}{|c|c|c|c|}
\hline Location and reference & Study group & Age & $\begin{array}{l}\text { Plasma } 25 \mathrm{OHD}(\mathrm{nmol} / \mathrm{l}) \text { mean } \pm \mathrm{SD} \\
\text { (if given), or median and range } \\
(n=\text { number of subjects where specified) }\end{array}$ \\
\hline
\end{tabular}

North Africa

Algeria [25]

Egypt [77]
Ethiopia [78]
Libya [79]
Libya [80]
Tunisia [81]
Tropical Africa
Gabon [82]
The Gambia [1] from data
collected by Dibba et al.
[32, 83]

The Gambia [26]

The Gambia [84]

The Gambia [85]

Guinea Bissau [27]

Kenya [55, 60]
Healthy women at term delivery:

Summer

Winter

Newborns:

Summer

Winter

Healthy children

Active rickets

Healthy men and non-pregnant women $(24 \mathrm{M}, 6 \mathrm{~F})$

Healthy women at term delivery $(n=31)$

Children with active rickets $(10 \mathrm{M}, 6 \mathrm{~F})$

Healthy women at term delivery

Cord blood

Healthy veiled or non-veiled non-pregnant women

Healthy term infants (44 M, $35 \mathrm{~F}$ ) at $0,3,6$ months

Healthy children

Children with non-active rickets

Children with active rickets

Lactating women 3 months postpartum

Healthy women

Healthy men and women

Healthy men and women (239 M, 255 F)

TB patients (221 M, $142 \mathrm{~F})$

Healthy controls (8 M, $7 \mathrm{~F})$

TB patients $(9 \mathrm{M}, 6 \mathrm{~F})$
Not specified

$$
\begin{aligned}
& 11.8 \pm 4.2^{\mathrm{a}}(n=56) \\
& 9.0 \pm 2.8(n=28)
\end{aligned}
$$

5 days

0-3 y

20-22 y

22-28 y

$0.25-2 \mathrm{y}$

26-45 y

20-60 y

$9.0 \pm 5.6(n=56)$

$7.6 \pm 2.1(n=28)$

$25.3 \pm 10.3(n=14)^{\mathrm{b}, \mathrm{r}}$

$9.3 \pm 7.3(n=31)$

$23.5{\text { (range } 18-29)^{\mathrm{c}}}^{\mathrm{C}}$

25 (range 17-46)

$24.9 \pm 22.4^{\mathrm{d}, \mathrm{r}}$

$34(13-75, n=19)^{\mathrm{d}, \mathrm{r}}$

$20(10-45, n=14)$

Veiled: $35.7^{\mathrm{e}}$

Non-veiled: 42.5

$0-0.5$ y

$8-12$ y

1-14 y

16-41 y

25-44 y

45-49 y

50-54 y

55-59 y

60-64 y

65-69 y

70-74 y

$75+\mathrm{y}$

60-75 y

Not specified

Mean (SD)

$33 \pm 7.4 \mathrm{y}$

$35 \pm 8.3 \mathrm{y}$

$80.9 \pm 22.8(n=11)^{\mathrm{e}}$
0 mo: $109.96 \pm 42.5^{\mathrm{a}}$

3 mo: $148.0 \pm 54.3(n=27)$

6 mo: $150.5 \pm 64(n=28)$

$95.0 \pm 19.6(n=44)^{\mathrm{f}, \mathrm{g}}$

$50.7 \pm 12.8(n=30)$

$42.4 \pm 13.8(n=13)$

All year: $64.9 \pm 18.5(n=28)^{\mathrm{e}}$

Jan-Mar: $64.1 \pm 14.1(n=9)$

Apr-Jun: $66.1 \pm 21.6(n=9)$

Jul-Sep: $54.7 \pm 15.0(n=5)$

Oct-Dec: $73.9 \pm 21.7(n=5)$

$113.3 \pm 26.5(n=12)$

$95.7 \pm 2.3(n=14)$

$83.6 \pm 19.4(n=21)$

$97.7 \pm 26.5(n=27)$

$87.3 \pm 25.1(n=13)$

$87.0 \pm 32.7(n=7)$

$72.3 \pm 19.8(n=8)$

M: $64.3 \pm 15.5(n=15)^{\mathrm{f}, \mathrm{g}}$

F: $72.8 \pm 17.5(n=15)$

$85.3 \pm 34.8^{\mathrm{g}, \mathrm{h}}$

$78.3 \pm 22.6$

Median and range

$65.5(26.25-114.75, n=15)^{\mathrm{i}, \mathrm{r}}$

$39.75(6.75-89.25, n=15)$ 
Table 2 continued

\begin{tabular}{|c|c|c|c|}
\hline Location and reference & Study group & Age & $\begin{array}{l}\text { Plasma } 25 \mathrm{OHD}(\mathrm{nmol} / \mathrm{l}) \text { mean } \pm \mathrm{SD} \\
\text { (if given), or median and range } \\
(n=\text { number of subjects where specified) }\end{array}$ \\
\hline Nigeria $[86,87]$ & $\begin{array}{l}\text { Healthy age matched children }(9 \mathrm{M}, 3 \mathrm{~F}) \\
\text { Active rickets }(7 \mathrm{M}, 3 \mathrm{~F})\end{array}$ & $3-5 y$ & $\begin{array}{l}41(29-50)^{\mathrm{j}, \mathrm{r}} \\
36(22-84)\end{array}$ \\
\hline Nigeria [88] & $\begin{array}{l}\text { Healthy children } \\
\text { Children with active rickets }\end{array}$ & $1-5 y$ & $\begin{array}{l}69 \pm 22(n=20)^{\mathrm{e}} \\
36 \pm 28(n=22)\end{array}$ \\
\hline Nigeria $[89,90]$ & $\begin{array}{l}\text { Healthy children } \\
\text { Children with active rickets }\end{array}$ & $1-5 y$ & $\begin{array}{l}63 \pm 17.8(n=47)^{\mathrm{e}} \\
43 \pm 33.5(n=37)\end{array}$ \\
\hline Nigeria [91] & $\begin{array}{l}\text { Healthy children (matched for sex, age, } \\
\text { religion, } 19 \mathrm{M}, 8 \mathrm{~F}) \\
\text { Active rickets }(12 \mathrm{M}, 4 \mathrm{~F})\end{array}$ & $0.8-7 \mathrm{y}$ & $\begin{array}{l}60.0 \pm 18.8(n=27)^{\mathrm{f}} \\
35.3 \pm 11.8(n=16)\end{array}$ \\
\hline Nigeria [92-94] & $\begin{array}{l}\text { Healthy children } \\
\text { Active rickets }\end{array}$ & $\begin{array}{l}\text { Median } 42 \text { mo } \\
\text { Median } 46 \text { mo }\end{array}$ & $\begin{array}{l}51.3 \pm 15.5^{\mathrm{e}} \\
34.8 \pm 25.5\end{array}$ \\
\hline Nigeria $[95,96]$ & $\begin{array}{l}\text { Healthy children }(6 \mathrm{M}, 4 \mathrm{~F}) \\
\text { Active rickets }(3 \mathrm{M}, 7 \mathrm{~F})\end{array}$ & $1-8 \mathrm{y}$ & $\begin{array}{l}52.3 \pm 7.3^{\mathrm{e}}(n=10) \\
24 \pm 11.3(n=10)\end{array}$ \\
\hline Nigeria [97-99] & $\begin{array}{l}\text { Healthy children }(6 \mathrm{M}, 9 \mathrm{~F}) \\
\text { Active rickets }(6 \mathrm{M}, 9 \mathrm{~F})\end{array}$ & $2-8 \mathrm{y}$ & $\begin{array}{l}37.5 \pm 11.5^{\mathrm{k}}(n=15) \\
37.5 \pm 13.5(n=15)\end{array}$ \\
\hline Nigeria [100] & $\begin{array}{l}\text { Healthy children ( } 5 \mathrm{M}, 4 \mathrm{~F}) \\
\text { Children with pneumonia ( } 15 \mathrm{M}, 9 \mathrm{~F})\end{array}$ & $0.5-5 \mathrm{y}$ & $\begin{array}{l}130 \pm 107(n=9) \\
104 \pm 59(n=18)\end{array}$ \\
\hline Nigeria [101] & Children's survey $(97 \mathrm{M}, 121 \mathrm{~F})$ & $6-35 \mathrm{mo}$ & $\begin{array}{l}\text { All: } 64.3 \pm 23.3^{\mathrm{e}}(n=218) \\
\text { Healthy: } 65 \pm 24(n=198) \\
\text { Rickets: } 56.5 \pm 11.8(n=20)\end{array}$ \\
\hline Nigeria [102] & Active rickets $(9 \mathrm{M}, 7 \mathrm{~F})$ & $1.2-2.0 \mathrm{y}$ & $28.5(\text { range } 17-40)^{\mathrm{f}}$ \\
\hline Nigeria $[87,103]$ & $\begin{array}{l}\text { Healthy women at term delivery } \\
\text { (10 in purdah, } 20 \text { not in purdah) }\end{array}$ & Not given & $\begin{array}{l}\text { Mean and range } \\
\text { Purdah: } 53(37-64)^{1, \mathrm{r}} \\
\text { Non-purdah: } 90(68-150)\end{array}$ \\
\hline & Cord bloods & & $\begin{array}{l}\text { Purdah: } 31(24-59) \\
\text { Non-purdah: } 58(35-79)\end{array}$ \\
\hline Zaire [104] & Healthy men $(n=33)$ & Mean 31 y & $65 \pm 39^{\mathrm{m}, \mathrm{r}}$ \\
\hline Southern Africa & & & \\
\hline South Africa [105] & Children with active rickets $(2 \mathrm{M}, 6 \mathrm{~F})$ & $4-13$ y & $48.9 \pm 10.1(n=8)^{\mathrm{n}, \mathrm{r}}$ \\
\hline South Africa [24] & 232 patients with hip fracture & $72.7 \pm 13 \mathrm{y}$ & $\begin{array}{l}\text { All: } 44.3 \pm 23^{\mathrm{n}, \mathrm{r}} \\
\text { Nov-June (s): } 51 \pm 26.9 \\
\text { June-Oct (w): } 38.1 \pm 17.0\end{array}$ \\
\hline South Africa [106] & $\begin{array}{l}\text { Survey of school children } \\
\text { M/F rural } \\
\text { M/F suburb } \\
\text { M/F urban }\end{array}$ & $7-12$ y & $\begin{array}{l}72.3 \pm 21.8(n=60)^{\mathrm{n}, \mathrm{r}} \\
77.3 \pm 23(n=60) \\
82.8 \pm 18.8(n=60)\end{array}$ \\
\hline South Africa [107] & Active rickets $(2 \mathrm{M}, 2 \mathrm{~F})$ & $4-14 \mathrm{y}$ & $62.5 \pm 21.5(n=4)^{\mathrm{n}, \mathrm{r}}$ \\
\hline South Africa [108] & Survey of pre-school children & $3-5 y$ & $85.5 \pm 19(n=20)^{\mathrm{o}, \mathrm{r}}$ \\
\hline South Africa [109] & Healthy black children & $6-18$ y & $\begin{array}{l}6-9 \text { y: } 123.9 \pm 12.0(n=17)^{\mathrm{e}} \\
10-13 \text { y: } 115.6 \pm 5.7(n=26) \\
14-18 \text { y: } 90.2 \pm 10.8(n=15)\end{array}$ \\
\hline & Healthy albino children & $6-18$ y & $\begin{array}{l}6-9 \text { y: } 102.9 \pm 11.4(n=30) \\
10-13 \text { y: } 86.1 \pm 14.0(n=36) \\
14-18 \text { y: } 90.7 \pm 3.4(n=16)\end{array}$ \\
\hline
\end{tabular}


Table 2 continued

\begin{tabular}{|c|c|c|c|}
\hline Location and reference & Study group & Age & $\begin{array}{l}\text { Plasma } 25 \mathrm{OHD}(\mathrm{nmol} / \mathrm{l}) \text { mean } \pm \mathrm{SD} \\
\text { (if given), or median and range } \\
(n=\text { number of subjects where specified) }\end{array}$ \\
\hline \multirow[t]{4}{*}{ South Africa [110] } & Children: & $1-12$ y & \\
\hline & Active vitamin $\mathrm{D}$ or Ca deficiency rickets & & $32.3 \pm 18.8(n=21)^{\mathrm{o}, \mathrm{r}}$ \\
\hline & Hypophosphataemic rickets & & $52.5 \pm 12.3(n=9)$ \\
\hline & Healing rickets & & $61.8 \pm 6.0(n=3)$ \\
\hline \multirow[t]{3}{*}{ South Africa [111] } & Active rickets: & Median (range) & \\
\hline & Calcipenia & 9.5 y $(1.7-18.0)$ & $38.5(15.3-111.5)^{\mathrm{p}, \mathrm{r}}$ \\
\hline & Phosphopenia & 5.7 y $(0.3-16.0)$ & $26.0(10.0-62.5)$ \\
\hline South Africa [112] & $\begin{array}{l}\text { Healthy women at term delivery } \\
\text { Cord blood }\end{array}$ & $16-40 \mathrm{y}$ & $\begin{array}{l}81.75 \pm 28.8(n=43)^{\mathrm{q}, \mathrm{r}} \\
170.97 \pm 72.6(n=43)\end{array}$ \\
\hline South Africa [113] & Elderly female nursing home residents & $80 \pm 4 y$ & $32 \pm 11(n=60)^{\mathrm{a}}$ \\
\hline \multirow[t]{5}{*}{ South Africa [114] } & Survey of women: & $20-64$ y & \\
\hline & Premenopausal black & & $48.3(17.0-114.0, n=74)^{\mathrm{n}, \mathrm{r}}$ \\
\hline & Premenopausal white & & $65.8(34.0-114.8, n=105)$ \\
\hline & Postmenopausal black & & $47.5(15.8-80.8, n=65)$ \\
\hline & Postmenopausal white & & $64.5(25.5-139.8, n=50)$ \\
\hline
\end{tabular}

$y$ years, $m o$ months, $M$ male, $F$ female

${ }^{\text {a }}$ Not detailed

b Competitive binding assay [115]

${ }^{c}$ HPLC

d Competitive binding assay after extraction and HPLC

e RIA Incstar

f RIA Diasorin

g Participation in QA scheme DEQAS reported

h LC-MS/MS

${ }^{i}$ RIA [116]

${ }^{j}$ RIA after extraction [117]

${ }^{k}$ RIA Nicols after ethanol extraction

${ }^{1}$ Competitive binding assay [118]

${ }^{\mathrm{m}}$ Competitive binding assay [119]

${ }^{\mathrm{n}}$ Competitive binding assay [120]

${ }^{\circ}$ Competitive binding assay [121]

$\mathrm{p}$ Competitive binding assay (no details given)

${ }^{\mathrm{q}}$ Competitive binding assay [122]

${ }^{r}$ In-house assays

\section{References}

1. Prentice A. Vitamin D deficiency: a global perspective. Nutr Rev. 2008;66(suppl 2):S153-64.

2. Scientific Advisory Committee on Nutrition. Update on vitamin D. London: The Stationery Office; 2007.

3. Webb AR. Who, what, where and when-influences on cutaneous vitamin D synthesis. Prog Biophys Mol Biol. 2006;92:17-25.

4. Holick MF. Photobiology of vitamin D. In: Feldman D, Pike JW, Glorieux FH, editors. Vitamin D. 2nd ed. Burlington, MA: Elsevier Academic Press; 2005. p. 37-46.

5. Norman A. From vitamin D to hormone D: fundamentals of the vitamin D endocrine system essential for good health. Am J Clin Nutr. 2008;88:491S-9S.
6. Kimlin MG, Olds WJ, Moore MR. Location and vitamin D synthesis: is the hypothesis validated by geophysical data? J Photochem Photobiol B. 2007;86:234-9.

7. Schoenmakers I, Goldberg GR, Prentice A. Abundant sunshine and vitamin D deficiency. Br J Nutr. 2008;99:11713.

8. Prentice A, Goldberg GR, Schoenmakers I. Vitamin D across the lifecycle: physiology and biomarkers. Am J Clin Nutr. 2008;88:500S-6S.

9. Thacher TD. Calcium-deficiency rickets. Endocr Dev. 2003;6:105-25.

10. Wondale Y, Shiferaw F, Lulseged S. A systematic review of nutritional rickets in Ethiopia: status and prospects. Ethiop Med J. 2005;43:203-10. 
11. Lauridsen AL, Vestergaard P, Hermann AP, Brot C, Heickendorff L, Mosekilde L, et al. Plasma concentrations of 25hydroxy-vitamin $\mathrm{D}$ and 1,25-dihydroxy-vitamin $\mathrm{D}$ are related to the phenotype of Gc (vitamin D-binding protein): a cross-sectional study on 595 early postmenopausal women. Calcif Tissue Int. 2005;77:15-22.

12. Zella LA, Shevde NK, Hollis BW, Cooke NE, Pike JW. Vitamin D-binding protein influences total circulating levels of 1,25-dihydroxyvitamin D3 but does not directly modulate the bioactive levels of the hormone in vivo. Endocrinol. 2008;149:3656-67.

13. World Health Organisation Regional Offices for Africa and Eastern Mediterranean. The Africa Malaria Report 2006. Geneva: WHO; 2006.

14. World Health Organisation. World Health Statistics 2008. Geneva: WHO; 2008.

15. Lucas R, McMichael T, Smith W, Armstrong B. Solar ultraviolet radiation: global burden of disease from solar ultraviolet radiation. In: Pruss-Ustun A, Zeeb H, Mathers C, Repachoi M, editors. Environmental burden of disease series, no. 13. Geneva: World Health Organisation; 2006.

16. Quevedo WC, Fitzpatrick TB, Pathak MA, Jimbow K. Role of light in human skin color variation. Am J Phys Anthropol. 1975;43:393-408.

17. Cesarini JP, Roubin R, Fridman WH, Mouly R. Characterization of the infiltration of human malignant melanoma according to the nature of the receiving surface. I. Study of fragments of tumors. Ann Dermatol Syphiligr (Paris). 1976;103:312-5.

18. Malvy DJ, Guinot C, Preziosi P, Galan P, Chapuy MC, Maamer $\mathrm{M}$, et al. Relationship between vitamin $\mathrm{D}$ status and skin phototype in general adult population. Photochem Photobiol. 2000;71:466-9.

19. MacLaughlin J, Holick MF. Aging decreases the capacity of human skin to produce vitamin D3. J Clin Invest. 1985;76:1536-8.

20. Holick MF. Sunlight and vitamin D for bone health and prevention of autoimmune diseases, cancers, and cardiovascular disease. Am J Clin Nutr. 2004;80:1678S-88S.

21. Brazerol WF, McPhee AJ, Mimouni F, Specker BL, Tsang RC. Serial ultraviolet B exposure and serum 25 hydroxyvitamin D response in young adult American blacks and whites: no racial differences. J Am Coll Nutr. 1988;7:111-8.

22. Lo CW, Paris PW, Holick MF. Indian and Pakistani immigrants have the same capacity as Caucasians to produce vitamin D in response to ultraviolet irradiation. Am $\mathrm{J}$ Clin Nutr. 1986;44:683-5.

23. Jablonski NG, Chaplin G. The evolution of human skin coloration. J Hum Evol. 2000;39:57-106.

24. Pettifor JM, Ross FP, Solomon L. Seasonal variation in serum 25-hydroxycholecalciferol concentrations in elderly South African patients with fractures of femoral neck. Br Med J. 1978;1:826-7.

25. Garabedian M, Ben-Mekhbi H. Is Vitamin D-deficiency rickets a public health problem in France and Algeria? Rickets. 1991;21:215-21.

26. Prentice A, Yan L, Jarjou LM, Dibba B, Laskey MA, Stirling $\mathrm{DM}$, et al. Vitamin D status does not influence the breast-milk calcium concentration of lactating mothers accustomed to a low calcium intake. Acta Paediatr. 1997;86:1006-8.

27. Wejse C, Olesen R, Rabna P, Kaestel P, Gustafson P, Aaby P, et al. Serum 25-hydroxyvitamin D in a West African population of tuberculosis patients and unmatched healthy controls. Am J Clin Nutr. 2007;86:1376-83.

28. MacKeown JM, Cleaton-Jones PE, Edwards AW, TurgeonO'Brien H. Energy, macro- and micronutrient intake of 5-yearold urban black South African children in 1984 and 1995. Paediatr Perinat Epidemiol. 1998;12:297-312.
29. Murphy SP, Calloway DH, Beaton GH. Schoolchildren have similar predicted prevalences of inadequate intakes as toddlers in village populations in Egypt, Kenya and Mexico. Eur J Clin Nutr. 1995;49:647-57.

30. Bwibo NO, Neumann CG. The need for animal source foods by Kenyan children. J Nutr. 2003;133(suppl 2):3936S-40S.

31. Thacher TD, Fischer PR, Strand MA, Pettifor JM. Nutritional rickets around the world: causes and future directions. Ann Trop Paediatr. 2006;26:1-16.

32. Prentice A, Ceesay M, Nigdikar S, Allen SJ, Pettifor JM. FGF23 is elevated in Gambian children with rickets. Bone. 2008;42: 788-97.

33. Fawell J, Bailey K, Chilton J, Dahi E, Fewtrell L, Magara Y. Fluoride in drinking-water. London: World Health Organisation and IWA Publishing; 2006.

34. Pettifor JM, Schnitzler CM, Ross FP, Moodley GP. Endemic skeletal fluorosis in children: hypocalcaemia and the presence of renal resistance to parathyroid hormone. Bone Miner. 1989;7: 275-88.

35. Anon. The tropical intestine. Br Med J. 1972;1:2-3.

36. Menzies IS, Zuckerman MJ, Nukajam WS, Somasundaram SG, Murphy B, Jenkins AP, et al. Geography of intestinal permeability and absorption. Gut. 1999;44:483-9.

37. Mayoral LG, Tripathy K, Garcia FT, Klahr S, Bolanos O, Ghitis J. Malabsorption in the tropics: a second look. Am J Clin Nutr. 1967;20:866-83.

38. Falaiye JM. Present status of subclinical intestinal malabsorption in the tropics. Br Med J. 1971;4:454-8.

39. Lunn PG. Growth retardation and stunting of children in developing countries. Br J Nutr. 2002;88:109-10.

40. Breman JG. The ears of the hippopotamus: manifestations, determinants, and estimates of the malaria burden. Am J Trop Med Hyg. 2001;64:1-11.

41. Young DB, Perkins MD, Duncan K, Barry CE 3rd. Confronting the scientific obstacles to global control of tuberculosis. J Clin Invest. 2008;118:1255-65.

42. Chaisson RE, Martinson NA. Tuberculosis in Africa-combating an HIV-driven crisis. New Engl J Med. 2008;358:1089-92.

43. Amuna P, Zotor FB. Epidemiological and nutrition transition in developing countries: impact on human health and development. Proc Nutr Soc. 2008;67:82-90.

44. Boutayeb A. The double burden of communicable and noncommunicable diseases in developing countries. Trans Roy Soc Trop Med Hyg. 2006;100:191-9.

45. Mufunda J, Chatora R, Ndambakuwa Y, Nyarango P, Kosia A, Chifamba $J$, et al. Emerging non-communicable disease epidemic in Africa: preventive measures from the WHO Regional Office for Africa. Ethn Dis. 2006;16:521-6.

46. Vorster HH, Bourne LT, Venter CS, Oosthuizen W. Contribution of nutrition to the health transition in developing countries: a framework for research and intervention. Nutr Rev. 1999;57: $341-9$.

47. Davis CD. Vitamin D and cancer: current dilemmas and future research needs. Am J Clin Nutr. 2008;88:565S-9S.

48. Rajakumar K, Fernstrom JD, Holick MF, Janosky JE, Greenspan SL. Vitamin D status and response to Vitamin $\mathrm{D}(3)$ in obese vs. non-obese African American children. Obesity (Silver Spring). 2008;16:90-5.

49. Parkin DM, Sitas F, Chirenje M, Stein L, Abratt R, Wabinga H. Part I. Cancer in indigenous Africans-burden, distribution, and trends. Lancet Oncol. 2008;9:683-92.

50. Snyman JR, de Sommers K, Steinmann MA, Lizamore DJ. Effects of calcitriol on eosinophil activity and antibody responses in patients with schistosomiasis. Eur J Clin Pathol. 1997;52:277-80. 
51. Martineau AR, Honecker FU, Wilkinson RJ, Griffiths CJ. Vitamin D in the treatment of pulmonary tuberculosis. J Steroid Biochem Mol Biol. 2007;103:793-8.

52. Liu PT, Stenger S, Li H, Wenzel L, Tan BH, Krutzik SR, et al. Toll-like receptor triggering of a vitamin D-mediated human antimicrobial response. Science. 2006;311:1770-3.

53. Sasidharan PK, Rajeev E, Vijayakumari V. Tuberculosis and vitamin D deficiency. J Assoc Phys Ind. 2002;50:554-8.

54. Grange JM, Davies PD, Brown RC, Woodhead JS, Kardjito T. A study of vitamin D levels in Indonesian patients with untreated pulmonary tuberculosis. Tubercle. 1985;66:187-91.

55. Davies PD, Church HA, Brown RC, Woodhead JS. Raised serum calcium in tuberculosis patients in Africa. Eur J Respir Dis. 1987;71:341-4.

56. Davies PD, Brown RC, Woodhead JS. Serum concentrations of vitamin $\mathrm{D}$ metabolites in untreated tuberculosis. Thorax. 1985;40:187-90.

57. Wilkinson RJ, Llewelyn M, Toossi Z, Patel P, Pasvol G, Lalvani $A$, et al. Influence of vitamin $D$ deficiency and vitamin D receptor polymorphisms on tuberculosis among Gujarati Asians in west London: a case-control study. Lancet Oncol. 2000;355: 618-21.

58. Ustianowski A, Shaffer R, Collin S, Wilkinson RJ, Davidson RN. Prevalence and associations of vitamin D deficiency in foreign-born persons with tuberculosis in London. J Infect. 2005;50:432-7.

59. Sita-Lumsden A, Lapthorn G, Swaminathan R, Milburn HJ. Reactivation of tuberculosis and vitamin D deficiency: the contribution of diet and exposure to sunlight. Thorax. 2007;62: 1003-7.

60. Nnoaham KE, Clarke A. Low serum vitamin D levels and tuberculosis: a systematic review and meta-analysis. Int J Epidemiol. 2008;37:113-9.

61. Bellamy R, Ruwende C, Corrah T, McAdam KPWJ, Thursz M, Whittle HC, et al. Tuberculosis and chronic hepatitis B virus infection in Africans and variation in the vitamin D receptor gene. J Infect Dis. 1999;179:721-4.

62. Bolland MA, Grey A, Horne A, Thomas M. Osteomalacia in an HIV-infected man receiving rifabutin, a cytochrome $\mathrm{P} 450$ enzyme inducer: a case report. Ann Clin Microbiol Antimicrob. 2008;7:3.

63. Olesen R, Wejse C, Velez DR, Bisseye C, Sodemann M, Aaby P, et al. DC-SIGN (CD209), pentraxin 3 and vitamin D receptor gene variants associate with pulmonary tuberculosis risk in West Africans. Genes Immun. 2007;8:456-67.

64. Lombard Z, Dalton D-L, Venter PA, Williams RC, Bornman L. Association of HLA-DR, -DQ, and vitamin D receptor alleles and haplotypes with tuberculosis in the Venda of South Africa. Hum Immunol. 2006;67:643-54.

65. Babb C, van der Merwe L, Beyers N, Pheiffer C, Walzl G, Duncan K, et al. Vitamin D receptor gene polymorphisms and sputum conversion time in pulmonary tuberculosis patients. Tuberculosis (Edinb). 2007;87:295-302.

66. Fitness J, Floyd S, Warndorff DK, Sichali L, Malema S, Crampin AC, et al. Large-scale candidate gene study of tuberculosis susceptibility in the Karonga district of northern Malawi. Am J Trop Med Hyg. 2004;71:341-9.

67. Soborg C, Andersen AB, Range N, Malenganisho W, Friis H, Magnussen $\mathrm{P}$, et al. Influence of candidate susceptibility genes on tuberculosis in a high endemic region. Mol Immunol. 2007;44:2213-20.

68. Lewis SJ, Baker I, Davey Smith G. Meta-analysis of vitamin D receptor polymorphisms and pulmonary tuberculosis risk. Int $\mathbf{J}$ Tuberc Lung Dis. 2005;9:1174-7.
69. Adams JS, Liu P, Chun R, Modlin RL, Hewison M. Vitamin D in defense of the human immune response. Ann NY Acad Sci. 2007;1117:94-105.

70. Morcos MM, Gabr AA, Samuel S, Kamel M, el Baz M, el Beshry M, et al. Vitamin D administration to tuberculous children and its value. Boll Chim Farm. 1998;137:157-64.

71. Nursyam EW, Amin Z, Rumende CM. The effect of vitamin D as supplementary treatment in patients with moderately advanced pulmonary tuberculous lesion. Acta Med Indones. 2006;38:3-5.

72. Martineau ARR, Wilkinson J, Wilkinson KA, Newton SM, Kampmann B, Hall BM, et al. A single dose of vitamin D enhances immunity to mycobacteria. Am J Respir Crit Care Med. 2007;176:208-13.

73. Villamor E. A potential role for vitamin D on HIV infection? Nutr Rev. 2006;64:226-33.

74. Lensmeyer GL, Binkley N, Drezner MK. New horizons for assessment of vitamin D status in man. In: Seibel MJ, Robins SP, Bilezikian JP, editors. Dynamics of bone and cartilage metabolism. Principles and clinical applications. 2nd ed. New York: Academic Press; 2006. p. 513-28.

75. Hollis BW. Measuring 25-hydroxyvitamin D in a clinical environment: challenges and needs. Am J Clin Nutr. 2008;88: 507S-10S.

76. Muhe L, Lulseged S, Mason KE, Simoes EAF. Case-control study of the role of nutritional rickets in the risk of developing pneumonia in Ethiopian children. Lancet. 1997;349:1801-4.

77. Lawson DE, Cole TJ, Salem SI, Galal OM, el-Meligy R, AbdelAzim S, et al. Etiology of rickets in Egyptian children. Hum Nutr Clin Nutr. 1987;41:199-208.

78. Feleke Y, Abdulkadir J, Mshana R, Mekbib TA, Brunvand L, Berg JP, et al. Low levels of serum calcidiol in an African population compared to a North European population. Eur J Endocrinol. 1999;141:358-60.

79. Elzouki AY, Markestad T, Elgarrah M, Elhoni N, Aksnes L. Serum concentrations of vitamin D metabolites in rachitic Libyan children. J Pediatr Gastroenterol Nutr. 1989;9:507-12.

80. Markestad T, Elzouki A, Legnain M, Ulstein M, Aksnes L. Serum concentrations of vitamin D metabolites in maternal and umbilical cord blood of Libyan and Norwegian women. Hum Nutr Clin Nutr. 1984;38:55-62.

81. Meddeb N, Sahli H, Chahed M, Abdelmoula J, Feki M, Salah H, et al. Vitamin D deficiency in Tunisia. Osteoporos Int. $2005 ; 16: 180-3$.

82. Nguema-Asseko B, Ganga-Zandzou PS, Ovono F, Lendoye E, Lemamy GJ, Akendengue B, et al. Vitamin D status in Gabonese children. Arch Pediatr. 2005;12:1587-90.

83. Dibba B, Prentice A, Ceesay M, Stirling DM, Cole TJ, Poskitt EME. Effect of calcium supplementation on bone mineral accretion in Gambian children accustomed to a low-calcium diet. Am J Clin Nutr. 2000;71:544-9.

84. Aspray TJ, Yan L, Prentice A. Parathyroid hormone and rates of bone formation are raised in perimenopausal rural Gambian women. Bone. 2005;36:710-20.

85. Yan L, Schoenmakers I, Zhou B, Jarjou LM, Smith E, Nigdikar $\mathrm{SN}$, et al. Ethnic differences in parathyroid hormone secretion and mineral metabolism in response to oral phosphate administration. Bone submitted.

86. Okonofua F, Gill DS, Alabi ZO, Thomas M, Bell JL, Dandona P. Rickets in Nigerian children: a consequence of calcium malnutrition. Metabolism. 1991;40:209-13.

87. Okonofua FE. Calcium and vitamin D nutrition in Nigerian women and children. In: Thacher TD, editor. Nutritional rickets in Nigerian children: the way forward. Vevey, Switzerland: Nestle Nutrition; 2002. p. 17-21. 
88. Oginni LM, Worsfold M, Oyelami OA, Sharp CA, Powell DE, Davie MW. Etiology of rickets in Nigerian children. J Pediatr. 1996;128:692-4.

89. Oginni LM, Worsfold M, Sharp CA, Oyelami OA, Powell DE, Davie MW. Plasma osteocalcin in healthy Nigerian children and in children with calcium-deficiency rickets. Calcif Tissue Int. 1996;59:424-7.

90. Sharp CA, Oginni LM, Worsfold M, Oyelami OA, Risteli L, Risteli J, et al. Elevated collagen turnover in Nigerian children with calcium-deficiency rickets. Calcif Tissue Int. 1997;61:8794.

91. Walter EA, Scariano JK, Easington CR, Polaco AM, Hollis BW, Dasgupta A, et al. Rickets and protein malnutrition in northern Nigeria. J Trop Pediatr. 1997;43:98-102.

92. Thacher TD, Fischer PR, Pettifor JM, Lawson JO, Isichei CO, Reading JC, et al. A comparison of calcium, vitamin D, or both for nutritional rickets in Nigerian children. New Engl $\mathrm{J}$ Med. 1999:341:563-8.

93. Thacher TD, Fischer PR, Pettifor JM, Lawson JO, Isichei CO, Chan GM. Case-control study of factors associated with nutritional rickets in Nigerian children. J Pediatr. 2000;137:367-73.

94. Thacher TD. Medical treatment of rickets in Nigerian children. In: Thacher TD, editor. Nutritional rickets in Nigerian children: the way forward. Vevey, Switzerland: Nestle Nutrition; 2002. p. 44-7.

95. Thacher T, Glew RH, Isichei C, Lawson JO, Scariano JK, Hollis BW, et al. Rickets in Nigerian children: response to calcium supplementation. J Trop Pediatr. 1999;45:202-7.

96. VanderJagt DJ, Peery B, Thacher T, Pastuszyn A, Hollis BW, Glew RH. Aminoaciduria in calcium-deficiency rickets in northern Nigeria. J Trop Pediatr. 1999;45:258-64.

97. Pam S. Calcium absorption in Nigerian children with rickets. In: Thacher TD, editor. Nutritional rickets in Nigerian children: the way forward. Vevey, Switzerland: Nestle Nutrition; 2002. p. 635.

98. Graff M, Thacher TD, Fischer PR, Stadler D, Pam SD, Pettifor $\mathrm{JM}$, et al. Calcium absorption in Nigerian children with rickets. Am J Clin Nutr. 2004;80:1415-21.

99. Oramasionwu GE, Thacher TD, Pam SD, Pettifor JM, Abrams SA. Adaptation of calcium absorption during treatment of nutritional rickets in Nigerian children. Br J Nutr. 2008;100: 387-92.

100. Oduwole AO. Vitamin D nutrition in Nigerian children with pneumonia. In: Thacher TD, editor. Nutritional rickets in Nigerian children: the way forward. Vevey, Switzerland: Nestle Nutrition; 2002. p. 39-43.

101. Pfitzner MA, Thacher TD, Pettifor JM, Zoakah AI, Lawson JO, Isichei $\mathrm{CO}$, et al. Absence of vitamin $\mathrm{D}$ deficiency in young Nigerian children. J Pediatr. 1998;133:740-4.

102. Thacher TD, Fischer PR, Isichei CO, Pettifor JM. Early response to vitamin D2 in children with calcium deficiency rickets. J Pediatr. 2006;149:840-4.

103. Okonofua F, Houlder S, Bell J, Dandona P. Vitamin D nutrition in pregnant Nigerian women at term and their newborn infants. $\mathrm{J}$ Clin Pathol. 1986;39:650-3.

104. Buyamba-Kabangu JRM, Fagard R, Lijnen P, Bouillon R, Lissens W, Amery A. Calcium, vitamin D-endocrine system, and parathyroid hormone in black and white males. Calcif Tissue Int. 1987;41:70-4.
105. Pettifor JM, Ross P, Wang J, Moodley G, Couper-Smith J. Rickets in children of rural origin in South Africa: is low dietary calcium a factor. J Pediatr. 1978;92:320-4.

106. Pettifor JM, Ross P, Moodley G, Shuenyane E. Calcium deficiency in rural black children in South Africa-a comparison between rural and urban communities. Am J Clin Nutr. 1979;32:2477-83.

107. Pettifor JM, Ross FP, Travers R, Glorieux FH, Deluca HF. Dietary calcium deficiency: a syndrome associated with bone deformities and elevated serum 1,25-dihydroxyvitamin D concentrations. Metab Bone Dis Relat Res. 1981;2:301-5.

108. van der Westhuyzen J. Biochemical evaluation of black preschool children in the northern Transvaal. S Afr Med J. 1986;70:146-8.

109. Cornish DA, Maluleke V, Mhlanga T. An investigation into a possible relationship between vitamin $\mathrm{D}$, parathyroid hormone, calcium and magnesium in a normally pigmented and an albino rural black population in the Northern Province of South Africa. Biofactors. 2000;11:35-8.

110. Bhimma R, Pettifor JM, Coovadia HM, Moodley M, Adhikari M. Rickets in black children beyond infancy in Natal. S Afr Med J. 1995;85:668-72.

111. Daniels ED, Pettifor JM, Moodley GP. Serum osteocalcin has limited usefulness as a diagnostic marker for rickets. Eur J Pediatr. 2000;159:730-3.

112. Fairney A, Sloan MA, Patel KV, Coumbe A. Vitamin A and D status of black South African women and their babies. Hum Nutr Clin Nutr. 1987;41:81-7.

113. van Papendorp DH. The vitamin D status of South African women living in old-age homes. S Afr Med J. 1990;78:556.

114. Daniels ED, Pettifor JM, Schnitzler CM, Moodley GP, Zachen D. Differences in mineral homeostasis, volumetric bone mass and femoral neck axis length in black and white South African women. Osteoporos Int. 1997;7:105-12.

115. Lawson DE. Competitive binding assay for 25-hydroxyvitamin D using specific binding proteins. Methods Enzymol. 1980;67: 459-65.

116. Clemens TL, Hendy GN, Graham RF, Baggiolini EG, Oskokovic MR, O'Riordan JL. A radioimmunoassay for 1,25-dihydroxycholecalciferol. Clin Sci Mol Med. 1978;54:329-32.

117. Hummer L, Tjellesen L, Rickers H, Christiansen C. Measurement of 25-hydroxyvitamin D3 and 25-hydroxyvitamin D2 in clinical settings. Scand J Clin Lab Invest. 1984;44:595-601.

118. Preece MA, O'Riordan JL, Lawson DE, Kodicek E. A competitive protein-binding assay for 25-hydroxycholecalciferol and 25-hydroxyergocalciferol in serum. Clin Chem Acta. 1974;31: 235-42.

119. Bouillon R, Kerkhove PV, De Moor P. Measurement of 25hydroxyvitamin D3 in serum. Clin Chem. 1976;22:364-8.

120. Pettifor JM, Ross FP, Wang J. A competitive protein-binding assay for 25-hydroxyvitamin D. Clin Sci Mol Med Suppl. 1976; 51:605-7.

121. Haddah JG, Chyu KJ. Competitive protein-binding radioassay for 25-hydroxycholecalciferol. J Clin Endocrinol Metab. 1971; 33:992-5.

122. Fairney A, Turner C, Hanson S, Zambon M. A simple micromethod for 25-hydroxyvitamin D estimation. Ann Clin Biochem. 1979;16:106-10. 